Article

\title{
Serrulin: A Glycine-Rich Bioactive Peptide from the Hemolymph of the Yellow Tityus serrulatus Scorpion
}

\author{
Thiago de Jesus Oliveira ${ }^{1,2, *}$, Ursula Castro de Oliveira ${ }^{1}$ (ID and Pedro Ismael da Silva Junior ${ }^{1,2, *}$ \\ 1 Special Laboratory for Applied Toxinology (LETA), Butantan Institute, São Paulo CEP 05503-900, SP, Brazil \\ 2 Institute of Biomedical Sciences, University of São Paulo, São Paulo CEP 05508-900, SP, Brazil \\ * Correspondence: thiago.oliveira@butantan.gov.br or thijoli@hotmail.com (T.d.J.O.); \\ pedro.junior@butantan.gov.br (P.I.d.S.J.); Tel.: +55-11-96830-5482 (T.d.J.O.); +55-11-2627-9731 (P.I.d.S.J.)
}

Received: 26 June 2019; Accepted: 5 August 2019; Published: 6 September 2019

\begin{abstract}
Antimicrobial peptides (AMPs) are small molecules, which have a potential use as antibiotic or pharmacological tools. In chelicerate organisms, such as scorpions, these molecules constitute an alternative defense system against microorganisms. The aim of this work was to identify AMPs in the hemolymph of the Tityus serrulatus scorpion. Fractions of plasma and hemocytes were subjected to high-performance liquid chromatography (HPLC) and then analyzed to determine their activity in inhibiting microbial growth. One of the fractions from the hemocytes presents antimicrobial activity against microorganisms, such as Gram-negative and Gram-positive bacteria, fungi, and yeast. These fractions were analyzed by mass spectrometry, and a fragment of $3564 \mathrm{Da}$. was identified. The peptide was called serrulin, because it is derived from the species T. serrulatus. A comparison of the amino acid sequence of serrulin with databases shows that it has a similarity to the glycine-rich peptides described in Cupienius salai and Acanthoscurria gomesiana (spiders). Furthermore, serrulin has no hemolytic activity against human erythrocytes. While the presence of AMPs in T. serrulatus venom has been described in other works, this is the first work to characterize the presence of these molecules in the hemolymph (hemocytes) of this species and show its potential use as an alternative to conventional antibiotics against different species of microorganisms.
\end{abstract}

Keywords: antimicrobial peptide; glycine-rich peptide; innate immune system; scorpions; Tityus serrulatus

Key Contribution: Antimicrobial peptide from the hemolymph of the scorpion, Tityus serrulatus, shows activity against different microorganisms and a similarity to glycine-rich AMPs from spiders.

\section{Introduction}

In Brazil, there have been many studies on the species of yellow scorpion, Tityus serrulatus, which belongs to the Buthidae family. Scorpion stings are the most commonly reported accident of the reported accidents relating to venomous animals in Brazil, and the species T. serrulatus is considered one of the most dangerous species in Brazil [1]. T. serrulatus has a high proliferation by parthenogenesis [2] and is very common, mainly in Southeastern Brazil. T. serrulatus venom is composed mainly of neurotoxins that interact in molecular complexes that are essential cell membrane components (ion channels) [3]. The antimicrobial action of two T. serrulatus toxins (TsAP-1 and TsAP-2) and their analogs (TsAP-S1 and TsAP-S2) against microorganisms (bacteria and yeast), and their ability to inhibit the proliferation of human cancer cells $[4,5]$ have been evaluated. While there have been studies that elucidate the composition and toxicity of the venom, there are no researches that describe the functioning of the immune system or characterize the antimicrobial peptides (AMPs) from the hemolymph (plasma and hemocytes) of T. serrulatus. 
The innate immune system in invertebrates is basically composed of events involving cellular responses, including phagocytosis, nodulation, and encapsulation, and humoral responses, including the production of molecules from clotting and phenoloxidase cascade and the synthesis of AMPs $[6,7]$.

AMPs can be classified according to their amino acid sequence, three-dimensional (3D) structure, and action spectrum. Defensins are a group of AMPs that are amphipathic with cysteine residues, and they have patterns of conserved bonds that ensure their stability [8]. The overall similarity between the defensins of ticks and those of scorpions is up to $70 \%$, while the similarity between defensins of scorpions and those of insects is much lower [9]. Defensins have been described in the hemolymph from three different scorpions of the species Leiurius quinquestriatus, which was characterized as a defensin of $4321 \mathrm{Da}$ and shown to have activity against Gram-positive bacteria [10]. In the scorpion Androctonus australis, an androctonin molecule shows activity against Gram-negative and Gram-positive bacteria and fungi. Androctonin has two disulfide bridges and a molecular mass of $3076 \mathrm{Da}$. In the same study using Androctonus australis, buthinin, an antimicrobial peptide with a molecular mass of 4605 $\mathrm{Da}$, and which has activity against Gram-positive and Gram-negative bacteria and similarity to a defensin described in insects (Aeschna cyanea), was also described [11]. The most current work describing AMPs in the hemolymph of scorpions concerns a defensin found in the Centruroides limpidus limpidus. This defensin is denominated Cll-dlp (C. limpidus limpidus defensin-like peptide), presenting activity against Gram-positive and Gram-negative bacteria, with a molecular mass of $3821 \mathrm{Da}$ [12]. These studies were performed with the total hemolymph of scorpions, without separating the peptides present in the plasma and those present in the hemocytes. Therefore, it was not possible to indicate the location of these peptides.

The second AMP group contains the small open-end cyclic peptide, for example, the gomesin, isolated from the hemocytes of the spider Acanthoscurria gomesiana. Gomesin forms two internal disulfide bridges and adopts a $\beta$-hairpin-like fold. This peptide consists of 18 amino acids and has been tested against a variety of microorganisms [13]. The third group contains glycine-rich peptides. These AMPs are cationic and characterized by a high glycine content, for example, acanthoscurrins. These peptides are two isoforms isolated from the hemocytes of the spider Acanthoscurria gomesiana, and they have a positive charge and act against Gram-negative bacteria, Escherichia coli, and the yeast Candida albicans [14]. Ctenidins are glycine-rich AMPs from the hemocytes of the spider Cupiennius salei, and they are distinguished from acanthoscurrins by a sequence of 10 amino acids: VIDGKDDVGL. They also act against E. coli and Candida albicans [15].

The discovery of new AMPs from natural sources is of great importance for public health, since these molecules are pharmacological candidates due to their effective antimicrobial activity and low resistance rates [16]. AMPs have already been characterized in the hemolymph of different animals, such as acanthoscurrins and gomesin from the Acanthoscurria gomesiana spider $[13,14]$, Rondonin from the Acanthoscurria rondoniae spider [17], Lacrain from the "centipede" Scolopendra viridicornis [18], and a fragment of a human fibrinogen peptide found in the hemolymph of Triatoma infestans [19]. All of these molecules are involved in the protection of these species and show how the discovery and characterization of bioactive peptides is very important and has a wide applicability, for example, selectivity towards cancer cells, with effects on cell proliferation [20].

In the present study, we isolated an AMP, serrulin, from the hemocytes of the scorpion $T$. serrulatus. We evaluated the antimicrobial and hemolytic activity, and mass spectrometry revealed a high percentage of glycine residues $(G)$ and a similarity to other glycine-rich peptides from spiders.

\section{Results and Discussion}

\subsection{Fractionation of Peptides from the Hemocytes}

After extraction of the hemolymph from the Tityus serrulatus scorpion, hemocytes and plasma were separated by centrifugation. The acid extract from hemocytes was applied to Sep-Pak ${ }^{\circledR} \mathrm{C} 18$ cartridges for pre-fractionation. The molecules were eluted by three successive concentrations of 
acetonitrile (ACN) $(5 \%, 40 \%$, and $80 \%)$ in acidified water (0.05\% TFA). All the material eluted at $40 \%$ ACN was subjected to RP-HPLC, and all fractions were tested against different microorganisms in a liquid growth inhibitory assay. The search for the hemocytes of the scorpion T. serrulatus showed the presence of five antimicrobial fractions $(6,2,30,34$, and 40) (Table 1), and the numbers correspond to the fraction number from a set of fractions.

Table 1. Antimicrobial activity fractions from hemocytes.

\begin{tabular}{cccccc}
\hline \multicolumn{7}{c}{ Microorganism } \\
\hline Hemocytes & Fractions & $\begin{array}{c}\text { Escherichia } \\
\text { coli SBS363 }\end{array}$ & $\begin{array}{c}\text { Micrococcus } \\
\text { luteus A270 }\end{array}$ & $\begin{array}{c}\text { Candida albicans } \\
\text { MDM8 }\end{array}$ & $\begin{array}{c}\text { Aspergillus } \\
\text { niger }\end{array}$ \\
\hline $5 \%$ & 6 & - & - & - & + \\
& 2 & + & + & + & + \\
$40 \%$ & 30 & + & + & + & + \\
& 34 & + & + & + & + \\
\hline
\end{tabular}

Antimicrobial fractions from the hemocytes of the scorpion Tityus serrulatus present activity against microorganisms. The fractions were pre-fractionated in three concentrations of acetonitrile (ACN) $(5 \%$, $40 \%$, and $80 \%$ ) using a Sep-Pak ${ }^{\circledR}$ Column, then the samples were subjected to high-performance liquid chromatography using a reverse-phase column (RP-HPLC). The fractions were analyzed in a liquid growth inhibition assay, and we found five antimicrobial fractions $(6,2,30,34$, and 40$)$.

Samples eluted in 5\% (Figure 1) and 40\% (Figure 2A) ACN, with $0.05 \%$ TFA, presented fractions with antimicrobial activity (marked with squares and/or circles). No fractions with antimicrobial activity were identified in the samples eluted in $80 \% \mathrm{ACN}$.

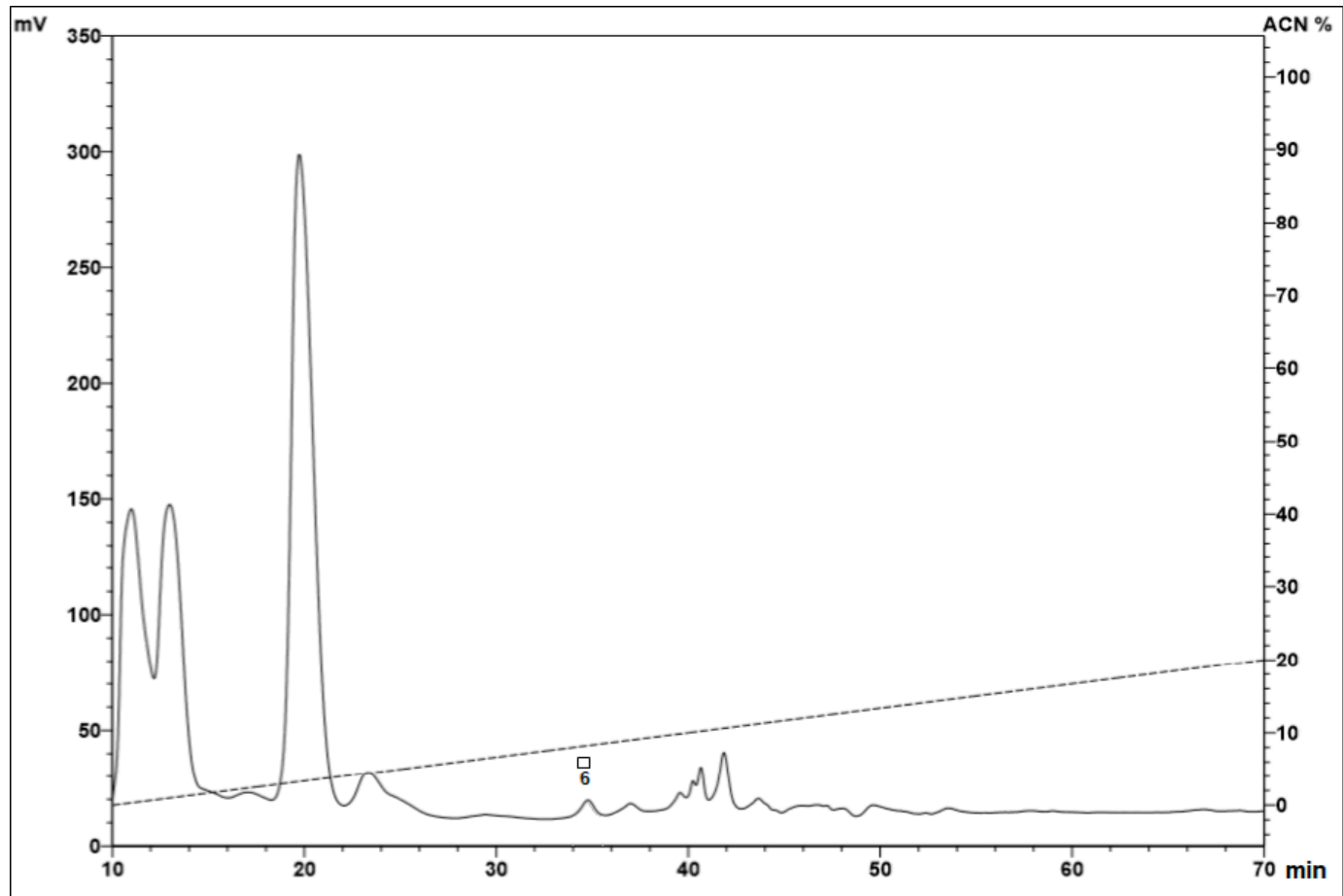

Figure 1. Reverse-phase high-performance liquid chromatography (RP-HPLC) of the hemocyte samples eluted at $5 \%$ acetonitrile $(\mathrm{ACN})$. After the fractionation step using a Sep-Pak ${ }^{\circledR} \mathrm{C} 18$ column, the samples eluted in 5\% ACN were subjected to a Jupiter ${ }^{\circledR} \mathrm{C} 18$ semi-preparative column, with a linear gradient from $0 \%$ to $20 \% \mathrm{ACN}$ (dotted line) in acidified water for $60 \mathrm{~min}(1.5 \mathrm{~mL} / \mathrm{min})$. The fractions were collected manually and submitted to a test of the inhibition of microbial growth in a liquid medium. Peaks with squares indicate the antimicrobial activities against Aspergillus niger ( $\square$ ). 


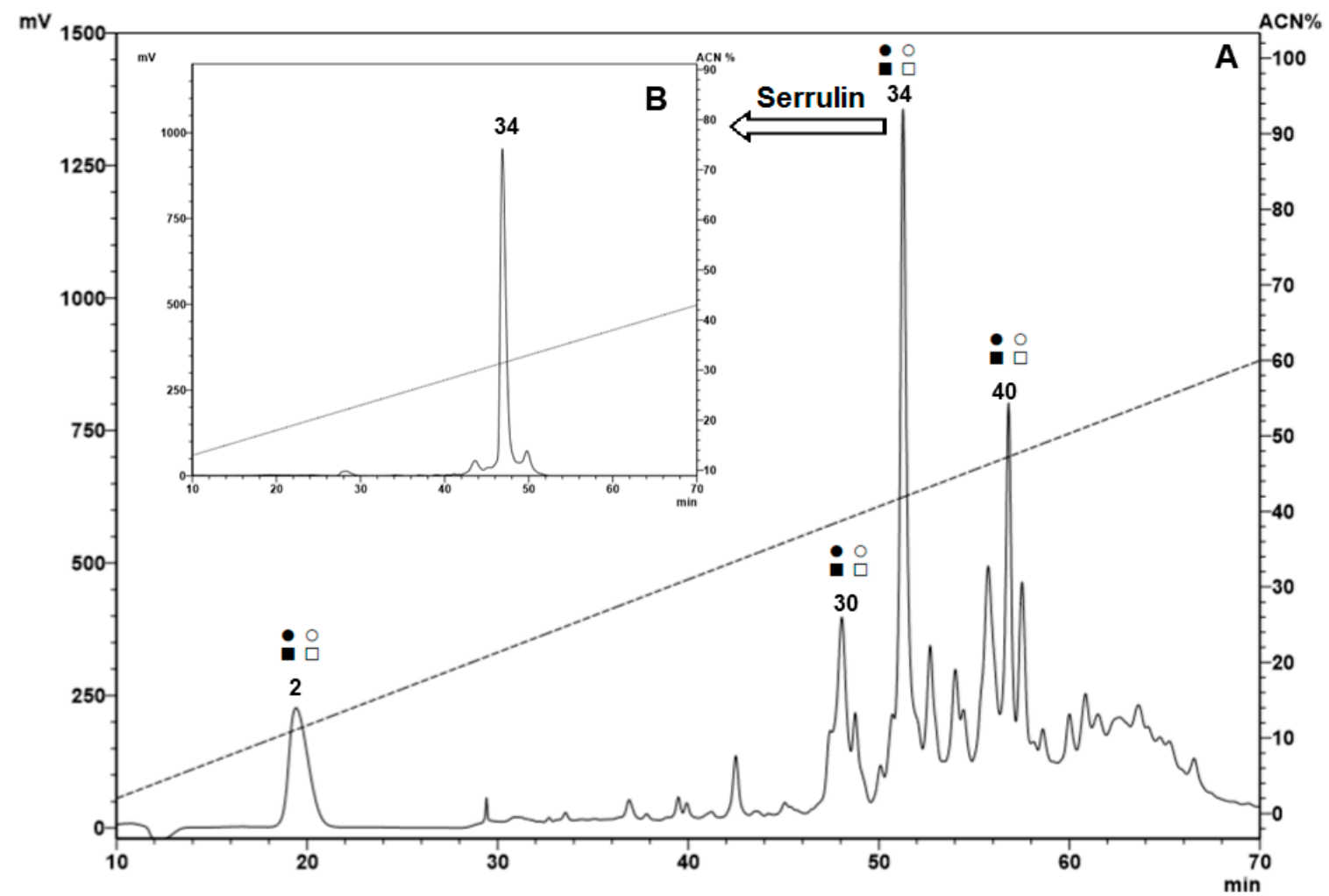

Figure 2. Reverse-phase high-performance liquid chromatography (RP-HPLC) of the hemocyte samples eluted at $40 \%$ acetonitrile (ACN). After the fractionation step using a Sep-Pak ${ }^{\circledR}$ C18 column, the samples eluted in $40 \% \mathrm{ACN}$ were subjected to a Jupiter ${ }^{\circledR} \mathrm{C} 18$ semi-preparative column, with a linear gradient from $2 \%$ to $60 \% \mathrm{ACN}$ (dotted line) in acidified water for $60 \mathrm{~min}$. The fractions were collected manually and submitted to a test of the inhibition of microbial growth in a liquid medium. Peaks with squares and circles indicate antimicrobial activities against the tested microorganisms: Escherichia coli SBS 363

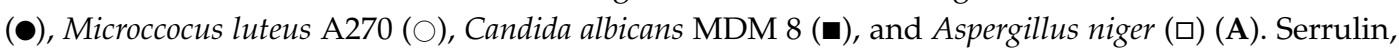
indicated with an arrow, was submitted to RP-HPLC using a Jupiter ${ }^{\circledR}$ C18 analytic-column, with a linear gradient from $13 \%$ to $43 \% \mathrm{ACN}$ (dotted line) in $0.05 \% \mathrm{TFA}$, for $60 \mathrm{~min}$. The fractions were collected manually and submitted to a test of the inhibition of microbial growth in a liquid medium and mass analyses (B).

The presence of the antimicrobial peptides characterized in other arthropods and eluted at $40 \%$ ACN may be justified by the amphipathic characteristic of many antimicrobial peptides $[11,12]$. One of the fractions from hemocytes eluted at $40 \%$ ACN in $0.05 \%$ TFA was selected. This fraction, with antimicrobial activity and a higher absorbance, was chosen for a forward analysis. This fraction was the major peak, compared with the other fractions (Figure 2A), and it was named serrulin, referring to the species T. serrulatus. The homogeneity of the fraction was verified by RP-HPLC (Figure 2B). The peaks were hand-collected, and the antimicrobial activity of the major peak was reconfirmed by the inhibition of microbial growth in a liquid medium.

The other fractions of the hemocytes that showed antimicrobial activity (fraction 6 eluted in $5 \%$ and fractions 2, 30, and 40 eluted in $40 \%$ ) were submitted to the same processes but were not as homogeneous as fraction 34 (serrulin). The analyses by mass spectrometry were not as satisfactory as the results obtained for fraction 34. We believe that these fractions could be other AMPs, for example, the small open-end cyclic peptide or defensins, which have already been described in relation to other scorpions. 


\subsection{Bioassay}

\subsubsection{Antimicrobial Activity, Minimal Inhibitory Concentration (MIC)}

The antimicrobial activity was measured by liquid growth inhibition in a liquid medium [21]. The native peptide of the T. serrulatus scorpion hemolymph, called serrulin, was screened against a species of Gram-positive and Gram-negative bacteria, filamentous fungus, and yeast. The minimal inhibitory concentration (MIC) of serrulin was: $1.87-3.75 \mu \mathrm{g} / \mathrm{mL}(0.5-1 \mu \mathrm{M})$ for Micrococcus luteus A270, 30-60 $\mu \mathrm{g} / \mathrm{mL}(9-16 \mu \mathrm{M})$ for Echerichia coli SBS 363, 0.05-0.1 $\mu \mathrm{g} / \mathrm{mL}(0.01-0.1 \mu \mathrm{M})$ for Pseudomonas aeruginosas, $12-24 \mu \mathrm{g} / \mathrm{mL}(3-6 \mu \mathrm{M})$ for Aspergillus niger, and 6-12 $\mathrm{gg} / \mathrm{mL}(1.5-3 \mu \mathrm{M})$ for Candida albicans MDM8 (Table 2). Compared with the other peptides isolated in the hemolymph of scorpions, serrulin shows a higher antimicrobial activity, mainly in the low concentrations that inhibited the growth of the bacteria Pseudomonas aeruginosas (MIC $=0.01-0.3$ ). The molecule acted against Gram-positive and Gram-negative bacteria, filamentous fungus, and yeast, but it was not possible to confirm if the target of the action was common for all of the microorganisms. Further experiments would be needed to elucidate the mechanisms of action of this molecule for the different tested microorganisms.

Table 2. Antimicrobial activity spectrum of serrulin.

\begin{tabular}{ccc}
\hline Strain & MIC $(\mu \mathrm{g} / \mathrm{mL})$ & $\mu \mathrm{M}$ \\
\hline Gram-positive bacteria & & \\
\hline Micrococcus luteus A270 & $1.87-3.75$ & $(0.5-1)$ \\
\hline Gram-negative bacteria & & \\
\hline Escherichia coli SBS 363 & $30-60$ & $(9-16)$ \\
\hline Pseudomonas aeruginosa ATCC 27853 & $0.05-0.1$ & $(0.01-0.3)$ \\
\hline Fungi & & \\
\hline Aspergillus niger & $12-24$ & $(3-6)$ \\
\hline Yeast & & $(1.5-3)$ \\
\hline Candida albicans MDM8
\end{tabular}

MIC, minimum inhibitory concentration $(\mu \mathrm{g} / \mathrm{mL}): \mu \mathrm{M}$. The MIC refers to the concentration necessary to achieve a growth inhibition of $100 \%$.

\subsubsection{Hemolytic Activity}

No hemolytic activity of serrulin was identified at high concentrations (up to $60 \mu \mathrm{g} / \mathrm{mL}$ ) against human erythrocytes. These results demonstrate that serrulin is not able to lyse human red blood cells (Figure S1).

\subsection{Sodium Dodecyl Sulfate-Polyacrylamide Gel (SDS-PAGE)}

Serrulin's action against microorganisms was detected by the inhibition of microbial growth in a liquid medium, and this fraction was submitted to another step of purification. The chromatographic profile (Figure $2 \mathrm{~B}$ ) revealed a single absorbed protein peak, which was eluted at 33\% ACN. The sample $(20 \mu \mathrm{g})$ was applied to SDS-PAGE 20\%, and the masses were compared to a molecular weight marker. Serrulin corresponds to a single peptide band between 3 and $6 \mathrm{kDa}$. (Figure 3), thereby confirming its homogeneity and approximate molecular mass. It is interesting to highlight that AMPs with masses of $4 \mathrm{kDa}$ have been described in the hemolymph of other scorpions, such as L. quinquestriatus [10], A. australis [11], and C. limpidus limpidus [12]. 


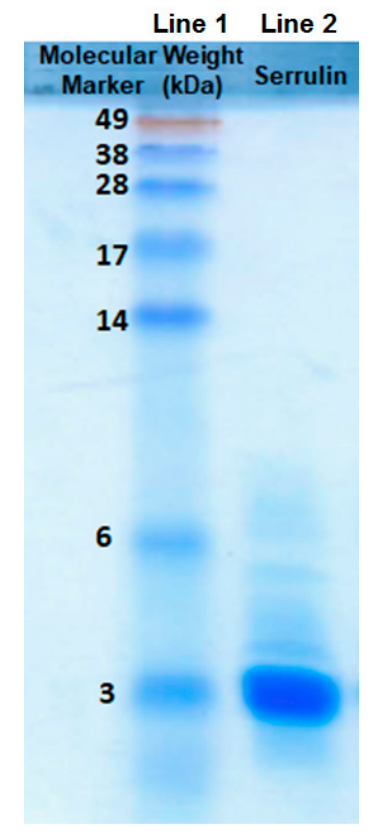

Figure 3. Sodium Dodecyl Sulfate Polyacrylamide Gel Electrophoresis 20\% (SDS-PAGE-20\%), stained with Coomasie-R Blue. Line 1, molecular weight marker (invitrogen SeeBlue ${ }^{\circledR}$ ), expressed in kDa; line 2 , serrulin in a non-reducing condition $(20 \mu \mathrm{g})$.

\subsection{Mass Spectrometry and Bioinformatics Analyses}

Aliquots of samples digested (by trypsin) and not digested were analyzed separately by mass spectrometry in an LC-MS/MS, coupled with an LTQ-Orbitrap Velos. The analysis of the undigested sample revealed a single molecule of $\mathrm{m} / \mathrm{z} 3564.0 \mathrm{Da}$ (Figure 4), thus corroborating the result that the observed mass in SDS-PAGE 20\% was above $3 \mathrm{kDa}$ (Figure 3).
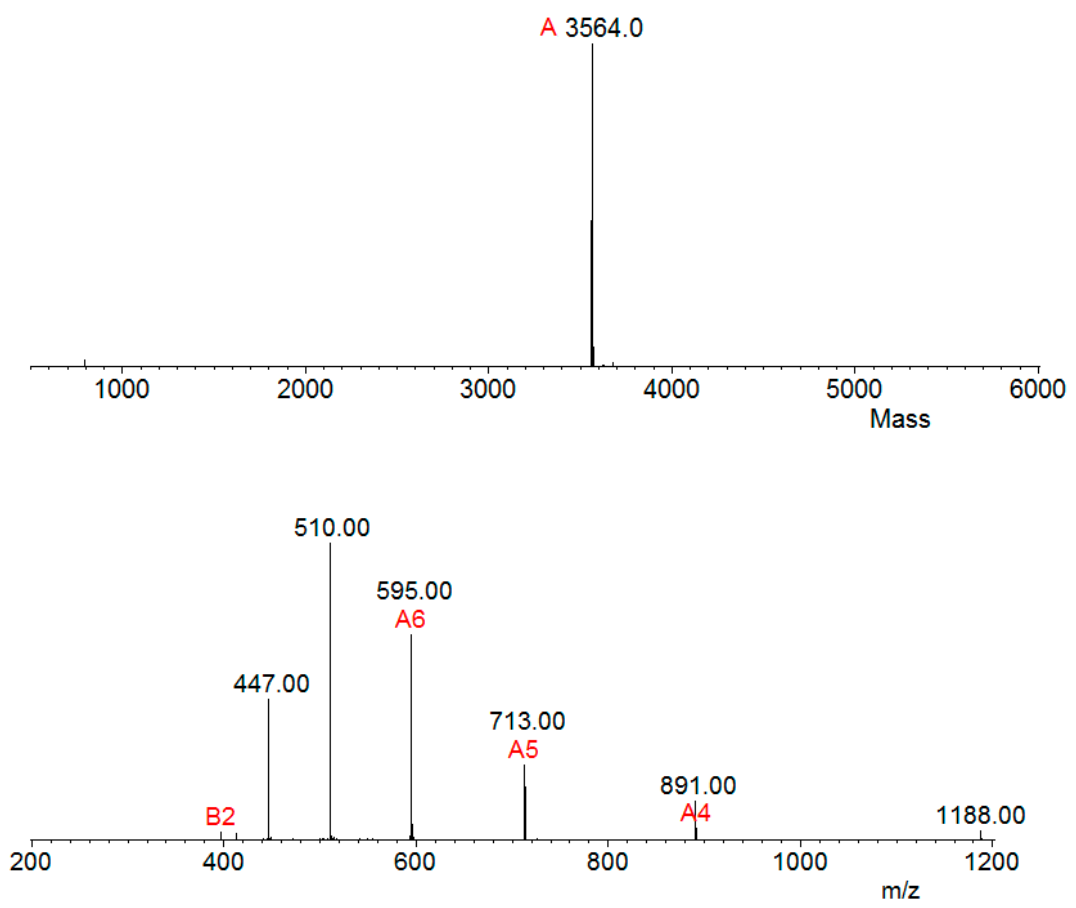

Figure 4. Serrulin spectrum. Mass spectrometry analyses (LC-MS/MS, coupled with a LTQ-Orbitrap Velos) of the peptide serrulin revealed an m/z of 3564.0 Da. Ions were submitted to MagTran ${ }^{\circledR}$ software. 
The analysis of serrulin spectra by PEAKS Studio software revealed a $3047 \mathrm{kDa}$ fragment, with a 97\% coverage, showing a sequence composed of 37 amino acids (GFGGGRGGFGGGRGGFGGGGIGGGGFGGGYGGGKIKG) (Figure 5), deposited in the database of transcripts of the T. serrulatus scorpion (midgut) [22] and its venom gland (telson) [23]. A mass near $3047 \mathrm{kDa}$ was identified in this sample by the MagTran ${ }^{\circledR}$ software (Figure 4), indicating that some amino acids were not identified in PEAKS Studio software. In addition, the PEAKS Studio software identified a post-translational modification (PTM) in serrulin and an amidated Lysine-Lys (K) in the C-terminal region (Figure 5).
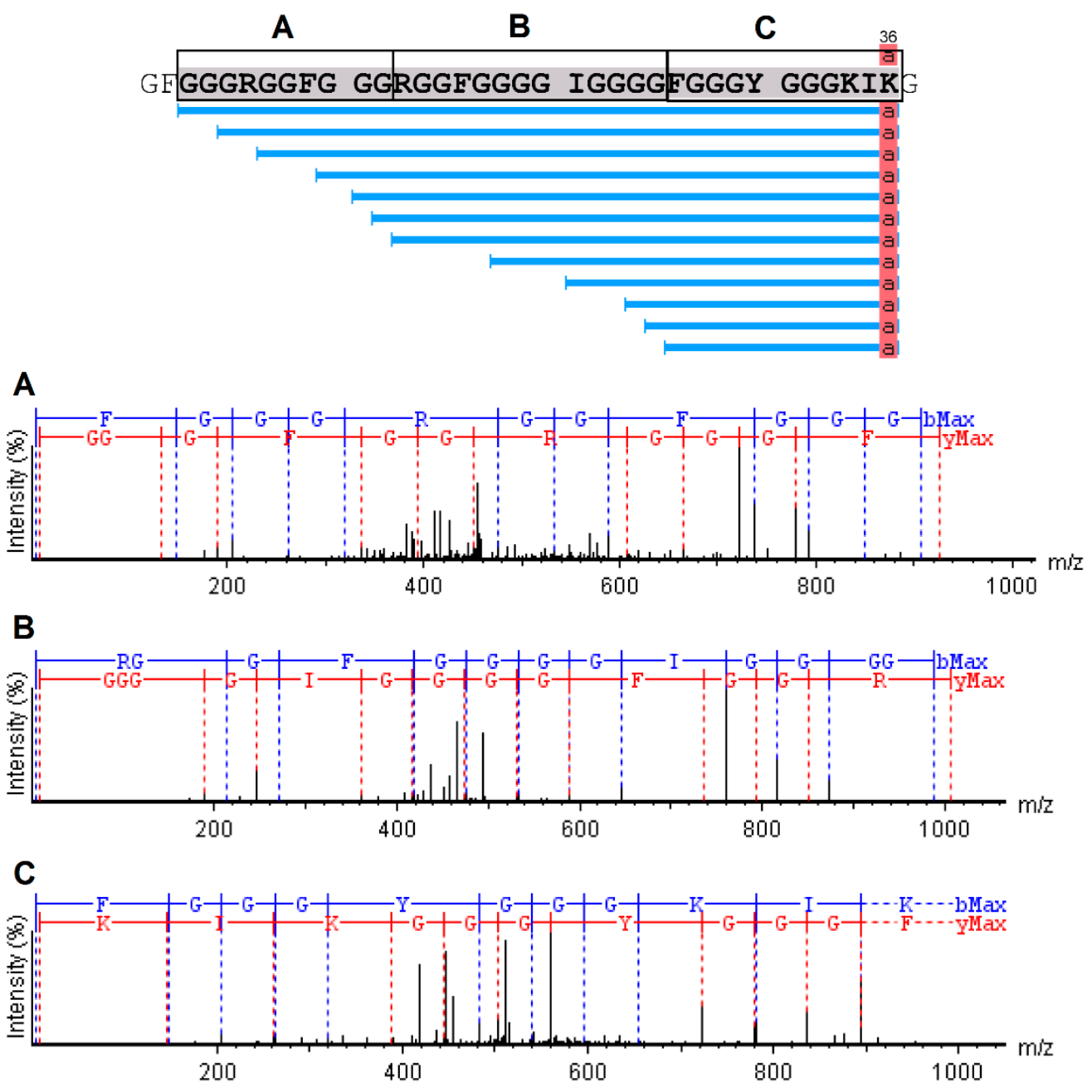

Figure 5. Collision-induced dissociation (CID) spectrum of the novo sequence from serrulin. The ions belonging to the $-\mathrm{y}$ (red) and $-\mathrm{b}$ (blue) series, indicated in the spectrum, correspond to the amino acid sequence of the peptide: GFGGGRGGFGGGRGGFGGGGIGGGGFGGGYGGGKIKG. The fragments of the sequenced peptide are represented by standard amino acid code letters.

A BLAST (basic local alignment search tool) was used to identify similar sequences, using the UniProt as a database (Arthropod), with an E-value threshold of $10^{-10}$. It is relevant to highlight two groups of molecules that showed similarity to serrulin. The first result is a fragment from the secreted glycine-rich protein found in ticks of the species Ixodes scapularis, with an identity of $68.1 \%$ (Figure S2). Many peptides were identified, especially in the saliva of the genus Ixodes [24,25]. While none of these sequences corresponded to AMPs or had known activities, they were proteins obtained by a direct submission from the Ixodes scapularis Genome Project and did not have confirmed antimicrobial activity [26]. 
The second result, obtained by a database search, corresponds to two AMPs from the hemolymph (hemocytes) of the spider Acanthoscurria gomesiana (Theraphosidae), acanthoscurrin 1 (Acantho 1) and acanthoscurrin 2 (Acantho 2). Both are molecules classified as glycine-rich antimicrobial peptides. Serrulin has a similarity of $63 \%$ to Acantho 2. The alignment of serrulin with the last 37 amino acids of Acantho 1 and Acantho 2 shows a conserved sequence of amino acids in the C-terminal region (Figure 6). It is very interesting to note that, in both, serrulin and acanthoscurins have an amidation of the lysine residue in the C-terminal. Acanthoscurrins has a marked activity against $C$. albicans (MIC $=1.15-2.3 \mu \mathrm{M})$ and E. coli $(\mathrm{MIC}=2.3-5.6 \mu \mathrm{M})$ [14]. Despite the similarity in the glycine content and activity of serrulin and acanthoscurrins, serrulin presents remarkable differences from acanthoscurrins, for example, the mass of serrulin is $3564.0 \mathrm{Da}$, while that of Acantho 1 and Acantho 2 is $10169 \mathrm{Da}$ and $10225 \mathrm{Da}$, respectively. In addition, serrulin's activity against M. luteus and A. niger could be detected. It is interesting to note that there is an amidation of the lysine residue in the C-terminal in both serrulin and acanthoscurins (Figure 5), suggesting that this modification may be important for the activity of these molecules.

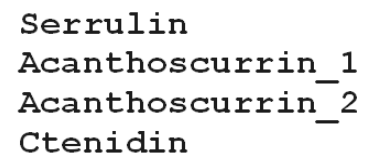

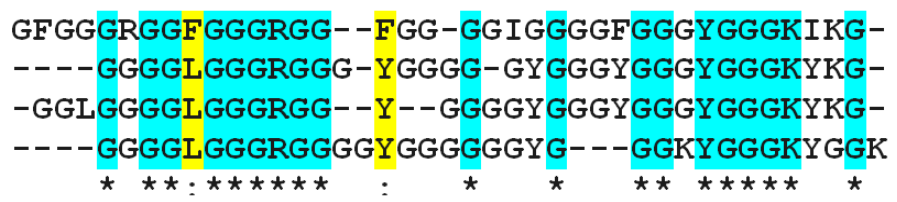

Figure 6. Alignment of the amino acid sequence of serrulin with other antimicrobial glycine-rich peptides. Using the UNIProt alignment, the serrulin sequence was aligned with AMPs: Acanthoscurrin 1, Acanthoscurrin 2, and Ctenidin. Amino acids that were identical in all sequences are shown in blue (or *), and minor modifications are shown in yellow or (:).

Ctenidins are antimicrobial glycine-rich peptides from the hemocytes of the mature female spider Cupiennius salei. Three molecules were isolated and denominated ctenidins $1-3$. The monoisotopic molecular masses were 8810, 9507, and $9564 \mathrm{Da}$. Ctenidins presented antimicrobial activity against $E$. coli $(\mathrm{MIC}=2.5-5 \mu \mathrm{M})$, and, with ctenidins, the growth of Staphylococcus aureus was reduced but not inhibited at concentrations of up to $10 \mu \mathrm{M}$. The amidation of the C-terminal of the mature peptide ctenidin is an ordinary modification of some AMPs from other organisms, such as chelicerates and crustaceans [27-29], making these peptides more stable. In addition, the amidation is present in both acanthoscurrins and serrulin.

In T. serrulatus transcripts databases, the fragment corresponding to serrulin was found to be a "protein not characterized". This is because the identification of the molecules is directly related to a structure research (midgut and venom gland), and serrulin is not a toxin or a protein involved in digestion. However, it may be present in these structures, because it is present in the hemolymph (whole body) of this species.

Analyses using the ExPASy ProtParam [30] tool indicate that serrulin is, like other AMPs, a cationic molecule, containing a positive charge $(+4)$ (Figure S3). Generally, cationic antimicrobial peptides act on the membrane of microorganisms by an electrostatic difference [31], but there are AMPs that act internally and can interact on ribosome, internal proteins, or nucleic acids (DNA or RNA) [32-34]. Like ctenidins and acanthoscurrins, the mechanism of action of serrulin was not identified in this work, so it is not possible to compare its characteristics with those of similar molecules.

The purification processes (Sep-Pak and HPLC), biological activities (antimicrobial activity, MIC, and hemolytic assay), characterization (SDS-Page), and computational data acquisition (mass analysis) yielded quantities of the native molecule that allowed us to initially identify and characterize serrulin. To elucidate its mechanisms of action, it would be necessary to extract more hemolymph and perform the purification processes again. 
It would be interesting to identify the site and mode of action of serrulin in the different microorganisms, but due to the difficult process of obtaining this molecule, we intend to carry out such studies with synthetic sequences of its conserved regions in the future.

\section{Conclusions}

We isolated and characterized an antimicrobial peptide from the hemolymph of the Tityus serrulayus scorpion, and we named this peptide serrulin, referring to the name of the species. Serrulin exhibits a similar primary structure to glycine-rich antimicrobial peptides, which have already been described in relation to other arachnids, such as ticks and spiders, and it has a molecular mass of $3564 \mathrm{Da}$. Serrulin shows antimicrobial activity against Gram-positive and Gram-negative bacteria, filamentous fungi, and yeast. However, serrulin does not present cytotoxicity against human erythrocytes at the tested concentrations. In this work, the first antimicrobial peptide from the hemolymph of the yellow scorpion, Tityus serrulatus, was described. This acts on the innate immune system of the scorpion to aid in its self-protection. Moreover, the study of this molecule can be of great interest for the discovery of a new antibiotic molecule that acts against resistant bacteria or a pharmacological tool.

\section{Material and Methods}

\subsection{Animals and Hemolymph Extraction}

Scorpions from the species Tityus serrulatus (Chelicerata, Buthidae) were collected in São Paulo and the Minas Gerais states and kept alive in a vivarium in the Special Laboratory for Applied Toxinology, under the licenses: Permanente Zoological Material Licenses 11024-3 IBAMA and Special Authorization for Access to Genetic Patrimony: 010345/2014-0, Instituto Butantan, São Paulo, Brazil.

This project was accepted by the Commission of Ethics regarding the use of Animals of the Butantan Institute (Comissão de Ética no Uso de Animais do Instituto Butantan), number: 1839260716, on 5 November 2018. The total hemolymph (about $1 \mathrm{~mL}$ ) was extracted from 50 individuals by cardiac puncture using a hypodermic needle. The hemolymph was extracted with a sodium citrate buffer (0.45 M NaCI; 0.1 M glucose; $30 \mathrm{mM}$ trisodium citrate; $26 \mathrm{mM}$ citric acid; and $10 \mathrm{mM}$ EDTA), $\mathrm{pH} 4.6$, to prevent hemocyte degranulation and clotting. The separation of the plasma and hemocytes was achieved through centrifugation in $800 \times g$ for $15 \mathrm{~min}$ at $4{ }^{\circ} \mathrm{C}$. The hemocytes were acidified in $5 \mathrm{~mL}$ of acetic acid 2 M (Synth, Diadema, Brazil), homogenized using a Dounce ${ }^{\circledR}$ homogenizer, and maintained under agitation on ice for $30 \mathrm{~min}$. Then, the sample was centrifuged at $16,000 \times g$ for $10 \mathrm{~min}$ at $4{ }^{\circ} \mathrm{C}$. The plasma was acidified in $20 \mathrm{~mL}$ of acidified ultrapure water [trifluoroacetic acid (TFA) $0.05 \%$ ]. The solution was maintained under agitation on ice for $30 \mathrm{~min}$, and the sample was centrifuged at $16,000 \times g$ for $10 \mathrm{~min}$ at $4{ }^{\circ} \mathrm{C}[35]$.

\subsection{Fractionation of Antimicrobial Peptides}

The supernatant of the plasma and hemocytes (separated) was loaded in Sep-Pak ${ }^{\circledR}$ C18 cartridges (Waters Corp., Milford, MA, USA), and the elution was performed with acetonitrile (ACN) (J.T.Baker ${ }^{\circledR}$; Avantor Performance Materials, Center Valley, PA, USA) at different concentrations ( $5 \%, 40 \%$, and $80 \%)$ and equilibrated in $0.05 \%$ TFA. The fractions were concentrated in a vacuum centrifuge (SpeedVac ${ }^{\mathrm{TM}}$ Savant ${ }^{\mathrm{TM}}$; Thermo Fisher Scientific, Waltham, MA, USA) and reconstituted with $1 \mathrm{~mL}$ of ultrapure water. Reverse-phase high-performance liquid chromatography (RP-HPLC) was carried out at room temperature on a Shimadzu LC-10 HPLC system. The column was a semi-preparative Jupiter ${ }^{\circledR}$ RP-C18 LC-Column $(10 \mu \mathrm{m}, 300 \AA, 250 \times 10 \mathrm{~mm})$ (Phenomenex International, Torrance, CA, USA). The elution was performed with a linear ACN gradient, equilibrated in $0.05 \%$ TFA for $60 \mathrm{~min}$ at a flow rate of $1.5 \mathrm{~mL} / \mathrm{min}(0-20 \%$ for the fraction eluted in $5 \%, 2-60 \%$ for the fraction eluted in $40 \%$, and $20-80 \%$ for the fraction eluted in $80 \%$ ). The absorbance was monitored at $225 \mathrm{~nm}$ and $280 \mathrm{~nm}$, and the fractions were hand-collected. Then, lyophilized fractions were suspended in $300 \mu \mathrm{L}$ ultrapure water for antimicrobial assays. 
The molecule described in this research, faction 34, was subjected to a second step of fractionation using a linear gradient of ACN (13-43\%) with $0.05 \%$ TFA for $60 \mathrm{~min}$ at a flow rate of $1.0 \mathrm{~mL} / \mathrm{min}$, and an analytic column Jupiter ${ }^{\circledR}$ C18 LC-Column $(10 \mu \mathrm{m} 300 \AA$ A, $250 \times 4.60 \mathrm{~mm})$ (Phenomenex International, Torrance, CA, USA), with ACN equilibrated in $0.05 \%$ TFA. The fractions were hand-collected.

\subsection{Bioassays}

The antimicrobial activity was monitored by a liquid growth inhibition assay against Gram-negative and Gram-positive bacteria, fungi, and yeast, provided by Dr. Pedro Ismael da Silva Junior at the Instituto Butantan, Brazil. Briefly, a suspension of the microorganisms collected in the mid-logarithmic growth phase was used. Bacteria were cultured in a medium containing a broth with a poor nutrient content $(\mathrm{PB})(1.0 \mathrm{~g}$ peptone in $100 \mathrm{~mL}$ of water containing $86 \mathrm{mM} \mathrm{NaCl}$ at $\mathrm{pH} 7.4$; $217 \mathrm{mOsm})$, and the fungi and yeast were cultured in a poor potato dextrose broth (1/2-strength PDB) ( $1.2 \mathrm{~g}$ potato dextrose in $100 \mathrm{~mL}$ of water at $\mathrm{pH} 5.0 ; 79 \mathrm{mOsm}$ ). The assay was carried out using $80 \mu \mathrm{L}$ of the microorganism suspension in 96-well sterile microtiter plates, and $20 \mu \mathrm{L}$ of the fraction was collected by HPLC, until the final volume of $100 \mu \mathrm{L}$ was obtained $\left(5 \times 10^{4}\right.$ microorganisms). The plates were incubated for $18 \mathrm{~h}$ and $24 \mathrm{~h}$ for bacteria and fungi/yeast, respectively, at $30^{\circ} \mathrm{C}$. Sterile water was used as a microbial growth control, and streptomycin or tetracycline was used as a control of the growth inhibition. Antimicrobial activity was determined by measuring the absorbance at $595 \mathrm{~nm}$.

The minimum inhibitory concentration (MIC) was determined against microorganisms, as described above, using a serial dilution of serrulin. MICs are expressed as the interval of the concentration $[a]-[b]$, where $[a]$ is the highest tested concentration at which the bacteria grow, and $[b]$ is the lowest concentration which causes a growth inhibition of $100 \%$ [21].

The hemolytic activity was tested using human erythrocytes from a healthy adult donor. The Ethics Committee was the University of Sao Paulo School of Medicine (USP) FMUSP, $\mathrm{n}^{\circ}$ 17526619.3.0000.0065. Cells were first washed three times in a phosphate-buffered saline (PBS) ( $35 \mathrm{mM}$ phosphate buffer, $0.15 \mathrm{M} \mathrm{NaCl}, \mathrm{pH}$ 7.4) by centrifugations at $700 \times g$ for five minutes. Then, a suspension of $3 \%(v / v)$ of washed erythrocytes was incubated with $50 \mu \mathrm{L}$ of serrulin and PBS in a 96-well plate (assays were conducted in triplicate) for $3 \mathrm{~h}$ at $37^{\circ} \mathrm{C}$ (with a final volume of $100 \mu \mathrm{L}$ ). The supernatant absorbance was measured at $405 \mathrm{~nm}$. The hemolysis percentage was expressed for a $100 \%$ lysis control (erythrocytes incubated with $0.1 \%$ Triton X-100, (Sigma-aldrich, St. Louis, MO, USA), and PBS was used as a negative control [36].

\subsection{Sodium Dodecyl Sulfate-Polyacrylamide Gel (SDS-PAGE)}

Sodium dodecyl sulfate-polyacrylamide gel electrophoresis (SDS-PAGE) was carried out, and proteins were stained with Coomassie blue R [37]. Thirty micrograms of serrulin, solubilized in $20 \mu \mathrm{L}$ of ultrapure water, and a sample buffer were submitted to electrophoresis under reducing (data not shown) and non-reducing conditions on $20 \%$ SDS-polyacrylamide gels, using invitrogen SeeBlue ${ }^{\circledR}$ (Life Technologies do Brasil, Itapevi, SP, Brazil ) as a molecular weight marker.

\subsection{Enzymatic "in Gel" Digestion}

The selected protein (serrulin) was cored from the gels and placed in a microcentrifuge tube. The band was de-stained in $0.5 \mathrm{~mL} \mathrm{50 \%} \mathrm{methanol} / 5 \%$ acetic acid overnight at room temperature, before dehydration in $200 \mu \mathrm{L}$ acetonitrile, followed by complete drying in a vacuum centrifuge. The proteins were reduced by the addition of $50 \mu \mathrm{L}$ Dithiothreitol-DTT $(10 \mathrm{mM})$ and alkylated by the addition of $50 \mu \mathrm{L}$ iodoacetamide-IAA ( $100 \mathrm{mM}$ ) (both for $30 \mathrm{~min}$ at room temperature). The band was dehydrated in $200 \mu \mathrm{L}$ acetonitrile and hydrated in $200 \mu \mathrm{L}$ ammonium bicarbonate $(100 \mathrm{mM})$. The dehydrated band was dried completely in a vacuum centrifuge and rehydrated in $50 \mu \mathrm{L}$ of $20 \mathrm{ng} \mu \mathrm{L}^{-1}$ ice-cold porcine trypsin (Sigma-aldrich ${ }^{\circledR}$ ). The digestion was carried out overnight at $37^{\circ} \mathrm{C}$. The tryptic peptides produced in the digestion were collected by successive extractions with $50 \mu \mathrm{L}$ (50 mM ammonium 
bicarbonate) and $50 \mu \mathrm{L}$ (50\% acetonitrile/5\% formic acid (twice)). The total extract was concentrated in a vacuum centrifuge [38].

\subsection{Mass Spectrometry and Bioinformatics Analyses}

The naive and tryptic fragments of serrulin were resuspended in formic acid $(0.1 \%)$ and injected into an EASY-nL II nanoflow liquid chromatography system (Thermo Fisher Scientific), in tandem with an LTQ-Orbitrap Velos mass spectrometer (Thermo Fisher Scientific), at a flow rate of $200 \mathrm{~nL} / \mathrm{min}$ and with a linear gradient (from $0 \%$ to $80 \%$ mobile phase B) $(0.1 \%$ formic acid in $100 \%$ acetonitrile) for $40 \mathrm{~min}$. Tryptic peptides were separated by a capillary reverse-phase C18 fritted-tip analytical column (ID $75 \mu \mathrm{m} \times$ OD $360 \mu \mathrm{m}, 10 \mathrm{~cm}$ length) and in-house packed with $5 \mu \mathrm{m}$ Aqua C18 (125 ^, Phenomenex, Torrance, CA, USA). The spectrometer was operated in a positive mode, and the 10 most intense peaks were selected for collision-induced dissociation (CID) fragmentation, after acquiring each full scan. For the fragment scans, the settings were: An isolation window of 2 Da; a max list size of 500; a time window of $30 \mathrm{~s}$; a minimum signal of 5000; an activation time of $10 \mathrm{~ms}$; and a normalized collision energy of $35 \%$ [39].

The raw data files (Xcalibur Raw File) were used in a PEAKS Studio software (version 8.5, Bioinformatics Solution, Waterloo, ON, Canada) search. The analysis involved a 10-ppm error tolerance for the precursor ions, and 0.6 Da for the fragment ions. Oxidation was considered a variable modification, and trypsin was considered enzyme-specific. The MS/MS spectra were searched against a transcriptomic midgut database of T. serrulatus (downloaded in FASTA format on 20 August 2018, from NCBI UniProtKB; http://www.uniprot.org/; 44,111 entries). The obtained amino acid sequence was subjected to a BLAST search against the GenBank (NCBI) and UNIPROT databases using the alignment tool Protein BLAST P (Target database = Arthropoda, E-Threshold = 10, Matrix = Auto, Gapped $=$ yes, Hits $=250$ ). For mass analysis by the deconvolution of the ions, the MagTran ${ }^{\circledR}$ Program, version 1.02, was used [40].

The physico-chemical parameters of serrulin (such as the total number of positively and negatively charged residues, molecular weight, and theoretical pI) were calculated using the ProtParam tool, available through the portal ExPASy of the Swiss Institute of Bioinformatics website (https://web. expasy.org/protparam/) [30].

Supplementary Materials: The following are available online at http://www.mdpi.com/2072-6651/11/9/517/s1, Figure S1: Hemolytic effects of serrulin on human erythrocytes. The concentration-response curve of the hemolytic activity of the peptide shows the maximum tested concentration $(50 \mu \mathrm{M})$, which is very similar to that of the negative control (phosphate-buffered saline (PBS). Figure S2: Physico-chemical parameters of serrulin. Data obtained by the sequence analysis, "GFGGGRGGFGGGRGGFGGGGIGGGGFGGGYGGGKIKG", in ExPASy ProtParam. Information on the following is provided: The theoretical pI, molecular weight, total number of negatively and positively charged residues, atomic composition, extinction coefficients and percentage of amino acids found in the sample. Figure S3: Results obtained by searching with BLAST (Basic Local Alignment Search Tool) using Uniprot (Universal Protein resource). The amino acid sequence of serrulin had a similarity of $68 \%$ to a protein found in the tick transcriptome of the species, Ixodes scapularis.

Author Contributions: Conceptualization, T.d.J.O., U.C.d.O. and P.I.d.S.J.; Data curation, T.d.J.O.; Formal analysis, T.d.J.O., U.C.d.O. and P.I.d.S.J.; Funding acquisition, T.d.J.O. and P.I.d.S.J.; Investigation, T.d.J.O., U.C.d.O. and P.I.d.S.J.; Methodology, T.d.J.O. and P.I.d.S.J.; Project administration, P.I.d.S.J.; Resources, P.I.d.S.J.; Supervision, P.I.d.S.J.; Validation, T.d.J.O. and P.I.d.S.J.; Writing—original draft, T.d.J.O.; Writing—review and editing, T.d.J.O., U.C.d.O. and P.I.d.S.J.

Funding: This research was funded by the Research Support Foundation of the State of São Paulo (FAPESP/CeTICS), (Grant No. 2013/07467-1) and the Brazilian National Council for Scientific and Technological Development (CNPq), Thiago de Jesus Oliveira (Grant No. 155303/2016-3) and Pedro Ismael da Silva Junior (Grant No. 472744/2012-7).

Conflicts of Interest: The authors declare no conflicts of interest.

\section{References}

1. Cologna, C.T.; Marcussi, S.; Giglio, J.R.; Soares, A.M.; Arantes, E.C. Tityus serrulatus scorpion venom and toxins: An overview. Protein Pept. Lett. 2009, 16, 920-932. [CrossRef] [PubMed] 
2. Schneider, M.C.; Cella, D.M. Karyotype conservation in 2 populations of the parthenogenetic scorpion Tityus serrulatus (Buthidae): rDNA and its associated heterochromatin are concentrated on only one chromosome. J. Hered. 2010, 101, 491-496. [CrossRef] [PubMed]

3. Possani, L.D.; Merino, E.; Corona, M.; Bolivar, F.; Becerril, B. Peptides and genes coding for scorpion toxins that affect ion-channels. Biochimie 2000, 82, 861-868. [CrossRef]

4. Guo, X.; Ma, C.; Du, Q.; Wei, R.; Wang, L.; Zhou, M.; Chen, T.; Shaw, C. Two peptides, TsAP-1 and TsAP-2, from the venom of the Brazilian yellow scorpion, Tityus serrulatus: Evaluation of their antimicrobial and anticancer activities. Biochimie 2013, 95, 1784-1794. [CrossRef] [PubMed]

5. Mahadevappa, R.; Ma, R.; Kwok, H.F. Venom Peptides: Improving Specificity in Cancer Therapy. Trends Cancer 2017, 3, 611-614. [CrossRef] [PubMed]

6. Fukuzawa, A.H.; Vellutini, B.C.; Lorenzini, D.M.; da Silva Junior, P.I.; Mortara, R.A.; da Silva, J.M.C.; Daffre, S. The roles of hemocytes in the immunity of the spider Acanthoscurria gomesiana. Dev. Comp. Immunol. 2008, 32, 716-725. [CrossRef]

7. Nentwing, L.K.; Nentwing, W. The Immune System of Spider. In Spider Ecophysiology; Nentwing, W., Ed.; Springer: Bern, Switzerland, 2013; 82p.

8. Froy, O.; Gurevitz, M. Arthropod and mollusk defensins-evolution by exon-shuffling. Trends Genet. 2003, 19, 684-687. [CrossRef] [PubMed]

9. Baumann, T.; Kuhn-Nentwig, L.; Largiadèr, C.R.; Nentwig, W. Expression of defensins in non-infected araneomorph spiders. Cell. Mol. Life Sci. 2010, 67, 2643-2651. [CrossRef]

10. Cociancich, S.; Goyffon, M.; Bontems, F.; Bulet, P.; Bouet, F.; Menez, A.; Hoffmann, J. Purification and characterization of a scorpion defensin, a $4 \mathrm{kDa}$ antibacterial peptide presenting structural similarities with insect defensins and scorpion toxins. Biochem. Biophys. Res. Commun. 1993, 194, 17-22. [CrossRef]

11. Ehret-Sabatier, L.; Loew, D.; Goyffon, M.; Fehlbaum, P.; Hoffmann, J.A.; van Dorsselaer, A.; Bulet, P. Characterization of novel cysteine-rich antimicrobial peptides from scorpion blood. J. Biol. Chem. 1996, 271, 29537-29544. [CrossRef]

12. De La Vega, R.R.; Garcia, B.I.; D'Ambrosio, C.; Diego-Garcia, E.; Scaloni, A.; Possani, L.D. Antimicrobial peptide induction in the haemolymph of the Mexican scorpion Centruroides limpidus limpidus in response to septic injury. Cell. Mol. Life Sci. 2004, 61, 1507-1519. [CrossRef] [PubMed]

13. Silva, P.I., Jr.; Daffre, S.; Bulet, P. Isolation and characterization of gomesin, an 18-residue cysteine-rich defense peptide from the spider Acanthoscurria gomesiana hemocytes with sequence similarities to horseshoe crab antimicrobial peptides of the tachyplesin family. J. Biol. Chem. 2000, 275, 33464-33470. [CrossRef] [PubMed]

14. Lorenzini, D.M.; da Silva, P.I., Jr.; Fogaça, A.C.; Bulet, P.; Daffre, S. Acanthoscurrin: A novel glycine-rich antimicrobial peptide constitutively expressed in the hemocytes of the spider Acanthoscurria gomesiana. Dev. Comp. Immunol. 2003, 7, 781-791. [CrossRef]

15. Baumann, T.; Kämpfer, U.; Schürch, S.; Schaller, J.; Largiadèr, C.; Nentwig, W.; Kuhn-Nentwig, L. Ctenidins: Antimicrobial glycine-rich peptides from the hemocytes of the spider Cupiennius salei. Cell. Mol. Life Sci. 2010, 67, 2787-2798. [CrossRef] [PubMed]

16. Peters, B.M.; Shirtliff, M.E.; Jabra-Rizk, M.A. Antimicrobial Peptides: Primeval molecules or future drogs? PLoS Pathog. 2010, 6, e1001067. [CrossRef] [PubMed]

17. Riciluca, K.C.; Sayegh, R.S.; Melo, R.L.; Silva, P.I., Jr. Rondonin an antifungal peptide from spider (Acanthoscurria rondoniae) haemolymph. Results Immunol. 2012, 2, 66-71. [CrossRef] [PubMed]

18. Chaparro, E.; da Silva, P.I., Jr. Lacrain: The first antimicrobial peptide from the body extract of the Brazilian centipede Scolopendra viridicornis. Int. J. Antimicrob. Agents 2016, 48, 277-285. [CrossRef] [PubMed]

19. Diniz, L.C.L.; Miranda, A.; da Silva, P.I., Jr. Human Antimicrobial Peptide Isolated from Triatoma infestans Haemolymph, Trypanosoma cruzi-Transmitting Vector. Front. Cell. Infect. Microbiol. 2018, 8, 354. [CrossRef] [PubMed]

20. Ikonomopoulou, M.P.; Fernandez-Rojo, M.A.; Pineda, S.S.; Cabezas-Sainz, P.; Winnen, B.; Morales, R.A.V.; Brust, A.; Sánchez, L.; Alewood, P.F.; Ramm, G.A.; et al. Gomesin inhibits melanoma growth by manipulating key signaling cascades that control cell death and proliferation. Sci. Rep. 2018, 8, 11519. [CrossRef] [PubMed]

21. Bulet, P.; Dimarcq, J.L.; Hetru, C.; Lagueux, M.; Charlet, M.; Hegy, G.; Van Dorsselaer, A.; Hoffmann, J.A. A novel inducible antibacterial peptide of Drosophila carries an O-glycosylated substitution. J. Biol. Chem. 1993, 268, 14893-14897. 
22. Fuzita, F.J.; Pinkse, M.W.; Patane, J.S.; Juliano, M.A.; Verhaert, P.D.; Lopes, A.R. Biochemical, transcriptomic and proteomic analyses of digestion in the scorpion Tityus serrulatus: Insights into function and evolution of digestion in an ancient arthropod. PLoS ONE 2015, 10, e0123841. [CrossRef] [PubMed]

23. de Oliveira, U.C.; Nishiyama, M.Y., Jr.; Dos Santos, M.B.V.; Santos-da-Silva, A.P.; Chalkidis, H.M.; Souza-Imberg, A.; Candido, D.M.; Yamanouye, N.; Dorce, V.A.C.; Junqueira-de-Azevedo, I.L.M. Proteomic endorsed transcriptomic profiles of venom glands from Tityus obscurus and T. serrulatus scorpions. PLoS ONE 2018, 13, e0193739. [CrossRef] [PubMed]

24. Wang, Y.; Zhu, S. The defensin gene family expansion in the tick Ixodes scapularis. Dev. Comp. Immunol. 2011, 35, 1128-1134. [CrossRef] [PubMed]

25. Miyoshi, N.; Isogai, E.; Hiramatsu, K.; Sasaki, T. Activity of tick antimicrobial peptide from Ixodes persulcatus (persulcatusin) against cell membranes of drug-resistant Staphylococcus aureus. J. Antibiot. 2017, 70, 142-146. [CrossRef] [PubMed]

26. Pagel Van Zee, J.; Geraci, N.S.; Guerrero, F.D.; Wikel, S.K.; Stuart, J.J.; Nene, V.M.; Hill, C.A. Tick genomics: The Ixodes genome project and beyond. Int. J. Parasitol. 2007, 37, 1297-1305. [CrossRef] [PubMed]

27. Herbinière, J.; Braquart-Varnier, C.; Grève, P.; Strub, J.M.; Frère, J.; Van Dorsselaer, A.; Martin, G. Armadillidin: A novel glycine-rich antibacterial peptide directed against gram-positive bacteria in the woodlouse Armadillidium vulgare (terrestrial isopod, Crustacean). Dev. Comp. Immunol. 2005, 29, 489-499. [CrossRef]

28. Destoumieux, D.; Bulet, P.; Loew, D.; Van Dorsselaer, A.; Rodriguez, J.; Bachère, E. Penaeidins, a new family of antimicrobial peptides isolated from the shrimp Penaeus vannamei (Decapoda). J. Biol. Chem. 1997, 272, 28398-28406. [CrossRef] [PubMed]

29. Nakamura, T.; Furunaka, H.; Miyata, T.; Tokunaga, F.; Muta, T.; Iwanaga, S.; Niwa, M.; Takao, T.; Shimonishi, Y. Tachyplesin, a class of antimicrobial peptide from the hemocytes of the horseshoe crab (Tachypleus tridentatus): Isolation and chemical structure. J. Biol. Chem. 1988, 263, 16709-16713. [PubMed]

30. Gasteiger, E.; Hoogland, C.; Gattiker, A.; Duvaud, S.; Wilkins, M.R.; Appel, R.D.; Bairoch, A. Protein Identification and Analysis Tools on the ExPASy Server. In The Proteomics Protocols Handbook; John, M.W., Ed.; Humans Press Inc.: Totowa, NJ, USA, 2005; pp. 571-607.

31. Shrestha, A.; Duwadi, D.; Jukosky, J.; Fiering, S.N. Cecropin-like antimicrobial peptide protects mice from lethal E.coli infection. PLoS ONE 2019, 14, e0220344. [CrossRef]

32. Park, C.B.; Kim, M.S.; Kim, S.C. A novel antimicrobial peptide from Bufo bufo gargarizans. Biochem. Biophys. Res. Commun. 1996, 218, 408-413. [CrossRef] [PubMed]

33. Sugiarto, H.; Yu, P.L. Mechanisms of action of ostrich beta-defensins against Escherichia coli. FEMS Microbiol. Lett. 2007, 270, 195-200. [CrossRef] [PubMed]

34. Casteels, P.; Ampe, C.; Jacobs, F.; Vaeck, M.; Tempst, P. Apidaecins:antibacterial peptides from honeybees. EMBO J. 1989, 8, 2387-2391. [CrossRef] [PubMed]

35. Söderhäll, K.; Smith, V.J. Separation of the haemocyte populations of Carcinus maenas and other marine decapods, and prophenoloxidase distribution. Dev. Comp. Immunol. 1983, 7, 229-239. [CrossRef]

36. Hao, G.; Shi, Y.H.; Tang, Y.L.; Le, G.W. The membrane action mechanism of analogs of the antimicrobial peptide Buforin 2. Peptides 2009, 30, 1421-1427. [CrossRef] [PubMed]

37. Laemmli, U.K. Cleavage of structural proteins during the assembly of the head of bacteriophage T4. Nature 1970, 227, 680-685. [CrossRef] [PubMed]

38. Hanna, S.L.; Sherman, N.E.; Kinter, M.T.; Goldberg, J.B. Comparison of proteins expressed by Pseudomonas aeruginosa strains representing initial and chronic isolates from a cystic fibrosis patient: An analysis by 2-D gel electrophoresis and capillary column liquid chromatography-tandem mass spectrometry. Microbiology 2000, 146, 2495-2508. [CrossRef] [PubMed]

39. Altschul, S.F.; Madden, T.L.; Schäffer, A.A.; Zhang, J.; Zhang, Z.; Miller, W.; Lipman, D.J. Gapped BLAST and PSI-BLAST: A new generation of protein database search programs. Nucleic Acids Res. 1997, 25, 3389-3402. [CrossRef]

40. Zhang, Z.; Marshall, A.G. A Universal Algorithm for Fast and Automated Charge State Deconvolution of Electrospray Mass-to_charge Ratio Spectra. J. Am. Soc. Mass Spectrom. 1998, 9, 225-233. [CrossRef]

(C) 2019 by the authors. Licensee MDPI, Basel, Switzerland. This article is an open access article distributed under the terms and conditions of the Creative Commons Attribution (CC BY) license (http://creativecommons.org/licenses/by/4.0/). 